\title{
PERLINDUNGAN HUKUM TERHADAP KONSUMEN KOSMETIK ILEGAL YANG MENGANDUNG BAHAN KIMIA BERBAHAYA
}

\author{
Enik Isnaini, SH.MH \\ Fakultas Hukum, Universitas Islam Lamongan \\ enikisnaini354@gmail.com \\ ABSTRAK
}

\begin{abstract}
Seiring dengan berkembangnya ilmu pengetahuan dan teknologi dari waktu ke waktu maka kebutuhan hidup manusia kian berkembang pula.Tidak hanya kebutuhan akan papan, sandang, pangan, kesehatan dan pendidikan saja. Kebutuhan untuk mempercantik atau memperindah diri pun sekarang menjadi prioritas utama di dalam menunjang penampilan sehari-hari. Pada era perdagangan bebas sekarang ini banyak kosmetik yang beredar di pasaran dengan beraneka jenis merek. Keinginan seorang wanita untuk selalu tampil cantik banyak dimanfaatkan oleh pelaku usaha yang tidak bertanggung jawab dengan cara memproduksi atau memperdagangkan kosmetik yang tidak memenuhi persyaratan atau aturan yang ada untuk di edarkan kepada masyarakat. Menurut Badan Pengawas Obat dan Makanan (BPOM) ada sejumlah kosmetik yang mengandung bahan yang berbahaya, antara lain berupa Bahan Kimia Obat (BKO) yang dapat membahayakan tubuh manusia. Oleh karena itu penggunaan bahan kimia obat yang mengandung bahan berbahaya dalam pembuatan kosmetik itu dilarang. Penegakan hukum yang tidak terlalu keras serta denda yang tidak diberatkan pada pelaku usaha kecil menyebabkan pelaku usaha tidak merasa jera serta pelaku usaha merasa tidak takut untuk mengedarkan kosmetik berbahaya yang tidak mempunyai izin edar tersebut karena sanksi yang lemah. Adanya Undang-Undang Nomor 8 Tahun 1999 tentang perlindungan konsumen diharapkan akan dapat memberikan pengaruh positif terhadap pelaku usaha dan konsumen, serta diharapkan dapat menjadi payung hukum untuk meminimalisir tindakan sewenang-wenang dari para pelaku usaha untuk melindungi kepentingan konsumen sehingga nantinya dapat menjamin tercapainya suatu perlindungan hukum bagi konsumen di Indonesia.
\end{abstract}

\section{Kata kunci : Perlindungan Konsumen, Sanksi Hukum, Kosmetik Ilegal}

\section{Pendahuluan}

Pada era perdagangan bebas sekarang ini banyak kosmetik yang beredar di pasaran dengan beraneka jenis merek. Keinginan seorang wanita untuk selalu tampil cantik banyak dimanfaatkan oleh pelaku usaha yang tidak bertanggung jawab dengan cara memproduksi atau memperdagangkan kosmetik yang tidak memenuhi persyaratan atau aturan yang ada untuk di edarkan kepada masyarakat.
Karena pada umumnya konsumen tidak mengetahui dari bahan apa suatu produk itu dibuat, bagaimana proses pembuatannya serta strategi pasar apa yang dijalankan untuk mendistribusikannya, maka diperlukan kaidah hukum yang dapat melindungi. Kebanyakan wanita sekarang ini sangat tertarik untuk membeli produk kosmetik dengan embel-embel harga yang murah serta hasilnya cepat terbukti atau terlihat. Oleh karena itu, banyak wanita yang 
memakai jalan alternatif untuk membeli suatu produk tanpa memperdulikan dampak yang ditimbulkanya walaupun produk kosmetik yang dibelinya tidak memenuhi suatu aturan dan persyaratan serta tidak terdaftar dalam BPOM. Kosmetik-kosmetik tersebut mudah didapatkan dengan harga yang murah karena tidak adanya nomor izin edar dari BPOM, tidak adanya tanggal kadaluwarsa produk, dan tidak adanya label bahan baku kosmetik. Karena harganya yang relatif murah, dan juga dapat dibeli dengan mudah karena ketersediaan barangnya sangat banyak beredar dipasaran sehingga kosmetik tanpa izin edar tersebut mudah dikonsumsi atau digunakan oleh masyarakat. Ketidaktahuan konsumen akan efek samping yang ditimbulkan dari kosmetik yang mengandung bahan berbahaya bisa dijadikan salah satu alasan mereka menggunakanya. Adanya UndangUndang Nomor 8 Tahun 1999 tentang perlindungan konsumen diharapkan akan dapat memberikan pengaruh positif terhadap pelaku usaha dan konsumen, serta diharapkan dapat menjadi payung hukum untuk meminimalisir tindakan sewenangwenang dari para pelaku usaha untuk melindungi kepentingan konsumen sehingga nantinya dapat menjamin tercapainya suatu perlindungan hukum bagi konsumen di Indonesia.

Pemerintah sebagai penyelenggara yang mempunyai peranan penting di dalam upaya perlindungan konsumen, pemerintah selaku penengah antara kepentingan pelaku usaha dan kepentingan konsumen, agar para pelaku usaha serta konsumen kegiatan jual belinya dapat berjalan dengan baik dan sesuai aturan yang ada seiring tanpa merugikan satu sama lain. Pemerintah juga harus bertanggung jawab di dalam pembinaan dan pengawasan penyelenggaraan perlindungan konsumen, untuk menjamin hal-hal konsumen.

\section{Metode Penelitian}

Penelitian hukum ini adalah penelitian yuridis normative, metode atau cara yang dipergunakan di dalam penelitian hukum yang dilakukan dengan cara meneliti bahan pustaka yang ada dan didasari pada bahan hukum primer dan sekunder.

\section{Hasil Peneitian dan Pembahasan}

Pengertian hak konsumen menurut Sudikno Martokusumo adalah kepentingan hukum yang dilindungi oleh hukum. Kepentingan sendiri berarti tuntutan yang diharapkan untuk dipenuhi. Sehingga dapat dikatakan bahwa hak adalah suatu tuntutan yang pemenuhannya dilindungi oleh hukum.

Hak konsumen diatur didalam Pasal 4 Undang-Undang Perlindungan Konsumen, yakni:

a) Hak atas kea manan, kenyamanan, dan keselamatan dalam mengkonsumsi barang dan/atau jasa 
b) Hak untuk memilih barang dan/atau jasa serta mendapatkan barang dan/atau jasa tersebut sesuai dengan nilai tukar dan kondisi serta jaminan yang dijanjikan

c) Hak atas informasi yang benar, jelas, dan jujur mengenai kondisi dan jaminan barang dan/atau jasa

d) Hak untuk didengar pendapat dan keluhannya atas barang dan/atau jasa yang digunakan

e) Hak untuk mendapatkan advokasi, perlindungan, dan upaya penyelesaian sengketa perlindungan konsumen secara patut

f) Hak untuk mendapat pembinaan dan pendidikan konsumen

g) Hak untuk diperlakukan atau dilayani secara benar dan jujur serta tidak diskriminatif

h) Hak untuk mendapatkan kompensasi, ganti rugi, dan/atau penggantian, apabila barang dan/atau jasa yang diterima tidak sesuai dengan perjanjian atau tidak sebagaimana mestinya

i) Hak-hak yang diatur dalam ketentuan perundang-undangan lainnya.

Bentuk perlindungan konsumen itu dapat dibedakan menjadi dua aspek yaitu :

1) Perlindungan terhadap kemungkinan barang yang diserahkan kepada konsumen tidak sesuai dengan apa yang telah disepakati.

2) Perlindungan konsumen diberlakukannya syarat-syarat yang tidak adil kepada konsumen.

Perbuatan pidana adalah perbuatan yang dilarang oleh suatu aturan hukum larangan yang mana disertai (sanksi) yang berupa pidana tertentu, bagi barangsiapa melanggar larangan tersebut, Sanksi tersebut dijatuhkan baik kepada perorangan maupun badan usaha yang telah melakukan perbuatan yang merugikan diri sendiri dan/atau orang lain, salah satunya memproduksi produk kosmetik menggunakan bahan-bahan berbahaya.

Adapun sanksi pidana bagi pelaku usaha yang memproduksi dan mengedarkan kosmetik yang mengandung bahan kimia berbahaya terdapat dalam:

1. Pasal 62 undang-undang nomor 8 tahun 1999

2. Pasal 8 undang-undang nomor 8 tahun 1999

3. Pasal 9 undang-undang nomor 8 tahun 1999

4. Pasal 63 undang-undang nomor 8 tahun 1999

5. Pasal 196 undang-undang nomor 36 tahun 2009

6. Pasal 197 undang-undang nomor 36 tahun 2009

7. Pasal 7 peraturan Kepala Badan Pengawas Obat dan Makanan Republik Indonesia nomor 7 tahun 2016

\section{Kesimpulan}

Dari Penelitian ini dapat diperoleh kesimpulan sebagai berikut : Kondisi Konsumen yang banyak dirugikan memerlukan peningkatan upaya untuk melindunginya, sehingga hak-haknya dapat ditegakkan namun disisi lain, perlindungan tersebut harus juga melindungi eksistensi produsen yang sangat esensial dalam perekonomian Negara. Oleh karena itu, diperlukan perundang-undangan yang dapat melindungi kedua belah pihak. Peraturanperaturan mengenai Perlindungan Hukum Bagi Konsumen Terhadap Peredaran Kosmetik Yang Mengandung Bahan Berbahaya dalam Undang-undang nomor 8 
Jurnal Independent Fakultas Hukum

tahun 1999 tentang perlindungan konsumen,

Undang-undang nomor 36 tahun 2009

tentang kesehatan. Peredaran Kosmetik

Yang Mengandung Bahan Berbahaya masih

banyak terjadi di masyarakat, maka dari itu

beberapa upaya penanggulangan

Perlindungan Hukum Bagi Konsumen

Terhadap Peredaran Kosmetik Yang

Mengandung Bahan Berbahaya harus

dikendalikan dari diri sendiri, lingkungan

masyarakat, dan pemerintah.

\section{Daftar Pustaka}

Ahmadi Miru, Prinsip-prinsip perlindungan hukum bagi konsumen di Indonesia, Jakarta: PT. Raja Grafindo, 2011

Andi Hamzah, Asas-asas Hukum Pidana, Rineka Cipta, jakarta, 2008.

Celina Tri Siwi Kristiyanti, Hukum Perlindungan konsumen, jakarta: Sinar Grafika, 2008.

Johnny ibrahim, teori dan penelitian hukum normatif, banyumedia publishing, malang, 2012.

Peter mahmud marzuki, penelitian hukum, universitas air langga, surabaya, 2005.

Zulham, hukum perlindungan konsumen, kencana pradana group, jakarta 2013. 